\title{
Protein pengikat hormon seks: sex hormone binding globulin (SHBG) dan aksi steroid seks
}

\author{
Assangga Guyansyah ${ }^{1}$ Mauritius Lambertus Edy Parwanto ${ }^{2}$
}

\begin{abstract}
ABSTRAK
Jumlah gen pada manusia sekitar 30000 gen, salah satunya yaitu gen SHBG (sex hormone binding globulin). Telah terbukti bahwa protein merupakan produk gen. Gen yang diekspresikan berarti mengkode sintesis protein. Pada studi ini mempelajari tentang protein sex hormone binding globulin (SHBG) yang merupakan produk gen SHBG. Gen SHBG terletak pada kromosom 17 p 3.1 di setiap sel tubuh kita. Gen SHBG pada hepatosit mengkode protein SHBG, protein tersebut selanjutnya disekresikan ke sistem sirkulasi. Gen SHBG di dalam hepatosit memiliki kesamaan dengan gen androgen binding protein (ABP) di sel Sertoli dalam testis.

Dalam sisntesis protein SHBG maupun ABP ada 2 tahap yaitu tahap sintesis prekursor protein dan tahap selanjutnya pematangan prekursor protein di badan Golgi dengan proses glikosilasi. Protein SHBG maupun ABP memiliki funsgi sama yaitu memperantarai aksi hormon steroid seks ke sel sasaran. Ikatan antara SHBG dengan steroid tersebut bersifat reversibel dan berafinitas tinggi untuk mengikat androgen (dehidrotestosteron/DHT, testosteron, 3a-androstenediol), sedangkan ikatan terhadap estrogen aktif maupun estradiol dengan afinitas yang lebih rendah. Aksi steroid seks ke sel sasaran telah terbukti dengan 2 cara yaitu cara pertama dengan berdifusi melewati membran sel sasaran dan cara kedua dengan sistem transduksi sinyal yang diperantarai oleh reseptor SHBG $\left(\mathrm{R}_{\text {SHBG }}\right)$ pada permukaan sel sasaran.

Protein SHBG di dalam sistem sirkulasi memiliki fungsi untuk mengikat hormon steroid seks dan memperantarai aksi hormon tersebut ke sel sasaran di luar testis, sedangkan ABP berfungsi memperantarai aksi hormon steroid seks di dalam testis.
\end{abstract}

Kata kunci : sex hormone binding globulin (SHBG), androgen binding globulin (ABP), steroid seks, reseptor SHBG $\left(\mathrm{R}_{{ }_{\mathrm{SHBG}}}\right.$ ), reseptor intraseluler

\author{
${ }^{1}$ Departemen Obstetri dan \\ Ginekologi, Fakultas Kedokteran, \\ Universitas Trisakti \\ ${ }^{2}$ Departemen Biologi Kedokteran, \\ Fakultas Kedokteran, Universitas \\ Trisakti

\section{Korespondensi:} \\ Parwanto, MLE \\ Departemen Biologi Kedokteran, \\ Fakultas Kedokteran, Universitas \\ Trisakti, Jalan Kyai Tapa No. \\ 260, Grogol, Jakarta Barat 11440, \\ Indonesia \\ Email: edyparwanto@trisakti.ac.id
}

J Biomedika Kesehat 2019;2(1):45-50 DOI: 10.18051/JBiomedKes.2019. v2.45-50

pISSN: 2621-539X / eISSN: 2621-5470

Artikel akses terbuka (open access) ini didistribusikan di bawah lisensi Creative Commons Attribution 4.0 International (CC-BY 4.0) 


\section{ABSTRACT}

\section{Sex hormone binding protein: sex hormone binding globulin (SHBG) and sex steroid action}

The number of human genes is around 30 000, one of which is the SHBG (sex hormone binding globulin) gene. It has been proven that protein is a product of genes. The expressed gene means coding for protein synthesis. In this literature study, sex hormone binding globulin (SHBG) protein which is a product of the SHBG gene. The SHBG gene is located on chromosome 17 p 3.1 in every cell in the body. The SHBG gene in hepatocytes encodes the SHBG protein, after the SHBG protein is synthesized and then secreted into the circulatory system. The SHBG gene in hepatocytes has similarities with the androgen binding protein (ABP) gene in Sertoli cells in the testes.

In the synthesis of SHBG and ABP proteins there are two stages, namely the synthesis of protein precursors and the next stage of maturation of protein precursors in the Golgi body by the glycosylation process. Both SHBG and ABP proteins have the same function, which is to mediate the action of sex steroid hormones into the target cells. The bond between SHBG and steroids is reversible and has a high affinity for binding to androgens (dehydrotestosterone/DHT, testosterone, $3 \alpha$-androstenediol), while binding to active estrogen and estradiol with lower affinity. The action of sex steroids on the target cells has been proven in 2 ways, namely the first way by diffusing through the target cell membrane and the second method with the signal transduction system mediated by the SHBG receptor $\left(\mathrm{R}_{-\mathrm{SHBG}}\right)$ on the surface of the target cell.

The SHBG protein in the circulatory system has a function to bind sex steroid hormones and mediate the action of these hormones to target cells outside the testis, while ABP functions to mediate the action of sex steroid hormones in the testis.

Keywords : sex hormone binding globulin (SHBG), androgen binding globulin (ABP), sex steroids, SHBG receptors $\left(\mathrm{R}_{\text {SHBG }}\right)$, intracellular receptors.

\section{PENDAHULUAN}

Pada prinsipnya protein merupakan produk gen. Gen yang diekspresikan berarti mengkode sintesis protein. Pada studi ini mempelajari tentang protein sex hormone binding globulin (SHBG) yang merupakan produk gen SHBG. Gen SHBG terletak pada kromosom 17 p 3.1 di setiap sel tubuh kita. Gen SHBG pada hepatosit mengkode protein SHBG, protein tersebut selanjutnya disekresikan ke sistem sirkulasi. Gen SHBG di dalam hepatosit memiliki kesamaan dengan gen androgen binding protein (ABP) di sel Sertoli dalam testis. Protein SHBG maupun ABP memiliki funsgi sama yaitu memperantarai aksi hormon steroid seks ke sel sasaran.

\section{Deoxyribonucleic acid (DNA) dan gen SHBG}

Tubuh kita disusun oleh berbagai jenis sel. Hampir seluruh jenis sel tubuh kita memiliki inti sel, kecuali sel darah merah (eritrosit). Di dalam inti sel tubuh kita mengandung kromosom. Di dalam kromosom mengandung asam deoksiribonukleat (ADN) atau deoxyribonucleic acid (DNA). Satu molekul DNA tersusun atas 1 molekul zat gula deoksiribosa, 1 basa nitrogen dan 1 gugus posfat. Molekul-molekul DNA tersebut saling berikatan sehingga membentuk benang tunggal DNA (DNA single stranded). DNA single stranded berpasangan dengan DNA single stranded yang lain sehingga terbentuk benang ganda DNA yang berbebntuk helix (DNA double helix). DNA double helix membentuk genom. Pada manusia, jumlah total genom haploid (23 kromosom) lebih dari 3 milyar pasang basa (base pair), maka pada sel somatik mengandung 2 kali lipatnya, yaitu sekitar 6 milyar genom. ${ }^{(1)}$ Jumlah gen pada manusia sekitar 30000 gen, salah satunya yaitu gen SHBG (sex hormone binding globulin).

Gen SHBG terdiri atas 4.3 kilobasa (kbs) ${ }^{(2)}$ terletak pada kromosom 17 p 3.1. ${ }^{(3)}$ Gen SHBG di dalam hepatosit berperan mengkode sintesis protein SHBG. Gen SHBG di dalam hepatosit memiliki kesamaan dengan gen androgen binding protein (ABP) di sel Sertoli dalam testis, ${ }^{(4,5)}$ sehingga $A B P$ juga disebut sebagai SHBG testis). (6) SHBG maupun ABP dikenal sebagai protein pengikat hormone steroid seks. SHBG sebelumnya dikenal dengan istilah sex steroid-binding protein (SBP) yang pertama kali diterima pada pertemuan ke 6 kelompok studi internasional untuk hormon steroid di Roma tahun 1969. Beberapa istilah yang kemudian diperkenalkan sehubungan dengan SBP, antara lain sex hormone-binding globulin (SHBG), testosterone-binding globulin atau testosterone-estradiol-binding globulin (TeBG), steroid-binding $b$ globulin (SBbG), estradiolbinding protein (EBP) dan androgen binding protein $(\mathrm{ABP}){ }^{(7)}$ 


\section{Sintesis SHBG}

Dalam sintesis protein SHBG ada 2 tahap, yaitu tahap awal dan tahap lanjutan. Pada tahap awal tersebut terjadi sintesis prekursor protein SHBG di ribosom, sedangkan tahap selanjutnya terjadi pematangan prekursor protein SHBG menjadi protein SHBG matang di dalam badan Golgi dengan proses glikosilasi. Prekursor protein SHBG mengandung residu asam amino sebanyak 403 asam amino, termasuk sinyal peptidanya. Jembatan disulfida pada prekursor protein SHBG terdapat pada 2 tempat, yaitu sistein 164 dengan sistein 188 dan sistein 333 dengan sistein 361. Glikosilasi pada prekursor protein SHBG manusia memiliki glikosilasi $\mathrm{O}$ dan glikosilasi N. Glikosilasi O (O-glycosylation) terjadi pada asam amino nomor 7 yaitu asam amino treonin. Glikosilasi N (N-glycosylation) pada precursor protein SHBG ada 2 tempat yaitu asparagin 351 dan asparagin 367. Bagian ikat reseptor SHBG terletak pada daerah dekat glikosilasi O. ${ }^{(8)}$

Komponen protein SHBG matang terdiri atas asam amino dan karbohidrat. Sebagian besar komponen SHBG adalah asam amino, sedangkan karbohidrat penyusunnya sebanyak $14 \% .{ }^{(9)}$ Protein SHBG matang tersebut kemudian disekresikan ke dalam sistem sirkulasi sebagai monomer atau subunit SHBG. Berbeda dengan SHBG, subunit ABP manusia terdiri atas 373 residu asam amino $(41.183 \mathrm{kDa})$ dan sinyal peptidanya 30 residu asam amino. ${ }^{(4,5,10)}$ Penelitian lebih lanjut memperlihatkan bahwa SHBG memiliki urutan asam amino yang sama dengan $\mathrm{ABP}$ sehingga disimpulkan keduanya dihasilkan oleh gen yang sama. ${ }^{(4,5)}$ Pendapat tersebut diperkuat oleh fakta bahwa satu gen mengkode sintesis prekursor protein SHBG dan $\mathrm{ABP}$ tetapi pengaturannya pada jaringan khusus. Perbedaan antara molekul SHBG dan ABP terlihat dalam rantai samping oligosakarida dan tempat berikatannya. ${ }^{(11)}$ Berdasar data tersebut dapat disimpulkan bahwa perbedaan tersebut terjadi saat pematangan precursor protein SHBG (glikosilasi).

Dalam proses pematangan prekursor protein SHBG, glikosilasi O lebih sederhana dibanding dengan glikosilasi N. Pada glikosilasi $\mathrm{O}$ tersebut hanya terjadi pada asam amino treanin, sedangkan glikosilasi $\mathrm{N}$ terjadi pada asam amino asparagin. Berdasar glikosilasi $\mathrm{N}$ tersebut, di populasi terdapat individu yang mengalami glikosilasi N pada molekul asparagin 351 dan 367 sehingga disebut individu dengan fenotip SHBG normal (wild-type $S H B G$ ), ${ }^{(8,12,13)}$ sedangkan pada individu dengan fenotip SHBG varian terjadi penambahan glikosilasi $\mathrm{N}$ pada molekul asparagin $327 .^{(8,14)}$

Secara molekuler, protein SHBG setelah disekresikan ke dalam sistem sirkulasi akan berperan sebagai subunit SHBG (monomer SHBG). Monomer SHBG merupakan glikoprotein plasma. Monomer SHBG tidak fungsional, oleh karena itu SHBG plasma berbentuk dimer yaitu gabungan antara 2 molekul monomer SHBG. Molekul dimer SHBG jika mengalami disosiasi menjadi monomer atau subunit. ${ }^{(15)}$ Hasil analisis terhadap subunit SHBG manusia memperlihatkan 373 residu asam amino dengan berat molekul 40.509 kilo Dalton $(\mathrm{kDa})^{(6)}$ dan sinyal peptidanya 29 residu asam amino. $^{(4,5)}$ Bagian ikat steroid (steroid binding site) berlokasi di antara kedua molekul sub-unit SHBG. Dimerisasi kedua molekul subunit SHBG sangat penting untuk mengikat steroid. ${ }^{(17,18)}$ Hasil penelitian memperlihatkan bahwa 2 molekul monomer SHBG yang membentuk 1 molekul dimer SHBG berikatan dengan 1 molekul steroid. (17) Hasil penelitian selanjutnya memperlihatkann bahwa asam amino metionin 139 pada molekul SHBG manusia merupakan komponen penting dari bagian ikat steroid. ${ }^{(19)}$

\section{SHBG memperantarai aksi steroid seks}

Telah diketahui bahwa di dalam sistem sirkulasi, SHBG berikatan dengan hormone seks steroid. Ikatan antara SHBG dengan steroid tersebut bersifat reversibel dan berafinitas tinggi untuk mengikat androgen (DHT, testosteron, 3a-androstenediol), sedangkan ikatan terhadap estrogen aktif maupun estradiol dengan afinitas yang lebih rendah. ${ }^{(8,20,21)}$ Pada pria, hormon seks steroid yaitu testosteron dihasilkan di dalam testis oleh sel Leydig. Setelah digunakan untuk spermatogenesis, testosteron masuk ke dalam sistem sirkulasi. Jumlah testosteron dalam sistem sirkulasi disebut testosteron total. Sudah sejak lama dilakukan penelitian untuk memperlihatkan persentase testosteron dalam sistem sirkulasi yang terikat oleh protein maupun dalam bentuk bebas.

Beberapa hasil penelitian memperlihatkan bahwa sebagian besar testosteron dalam sistem sirkulasi diikat oleh albumin yaitu 49.9\%, SHBG $44.3 \%$, cortisolbinding globulin (CBG) $3.56 \%$, dan 
sisanya sebagai testosteron bebas $2.23 \%{ }^{(22)}$ Selain itu juga telah diperlihatkan bahwa ada hubungan antara kadar steroid plasma dengan SHBG. ${ }^{20}$ Hasil penelitian terhadap pria Indonesia yang tinggal di Jakarta memperlihatkan bahwa kadar SHBG (nmol/L) mengikuti persamaan $\mathrm{Y}=48.849$ $0.328 *$ umur, sedangkan testosterone total $(\mathrm{nmol} / \mathrm{L})$ mengikuti persamaan $\mathrm{Y}=28.827-(0.224 * u m u r)$, dan kadar testosterone bebas (nmol/L) mengikuti persamaan $\mathrm{Y}=0.036+(0.001 *$ testosteron total $){ }^{(23)}$

Testosteron bebas dalam sistem sirkulasi bersifat fungsional (tersedia dan dapat digunakan oleh sel sasaran), sedangkan testosteron dalam bentuk yang terikat bersifat non fungsional (tidak tersedia dan tidak dapat digunakan oleh sel sasaran). Ikatan antara SHBG dan hormon seks steroid dalam aksinya ke sel sasaran ditemukan kemudian setelah teori difusi hormon seks steroid melewati membran sel sasaran. Sampai saat kami menyimpulkan ada 2 teori aksi hormon seks steroid terhadap sel sasaran, yaitu teori difusi melewati membrane sel $\operatorname{sasaran}^{(24,25)}$ dan teori transduksi sinyal. ${ }^{(25,26)}$

Pada teori difusi, hormone seks steroid melewati membran sel sasaran, kemudian di dalam sitoplasma hormone tersebut diikat oleh reseptor intra seluler. Sebelum mengikat hormone seks steroid, reseptor intraseluler dalam keadaan tidak aktif karena berikatan dengan inhibitor membentuk kompleks reseptor intraselulerinhibitor. Karena hormone seks steroid lebih kuat afinitasnya terhadap reseptor intraseluler, maka inhibitor pada kompleks tersebut dilepas, kemudian hormon seks steroid berikatan dengan reseptor intraseluler pada bagian ikat steroid (steroid binding site). Selanjutnya, kompleks protein reseptor intraseluler-steroid menjadi aktif dan secara langsung mengatur transkripsi gen khusus untuk merespon steroid. ${ }^{(24)}$

Pada teori transduksi sinyal, diawali dengan terjadinya ikatan antara SHBG dengan reseptor SHBG $\left(\mathrm{R}_{{ }_{\mathrm{SHBG}}}\right)$ sehingga membentuk kompleks reseptor SHBG dengan SHBG $\left(\mathrm{R}_{\mathrm{SHBG}^{-}}{ }^{-}\right.$ SHBG) pada membran sel. Selanjutnya, steroid bebas berikatan dengan $\mathrm{R}_{\mathrm{SHBG}}-\mathrm{SHBG}$. Steroid yang terikat tersebut kemudian mengaktifkan $\mathrm{R}_{\mathrm{SHBG}^{-}}{ }^{-}$ SHBG. ${ }^{(26)}$ Tahap berikutnya terjadi pengaktifan protein $\mathrm{G}$ oleh kompleks steroid-SHBG- $\mathrm{R}_{\text {SHBG }}$. (27) Pengaktifan protein $G$ tersebut penting untuk mengaktifkan adenil siklase. Adenil siklase yang aktif mengubah adenosine triphosphate (ATP) menjadi cyclic adenosine monophosphate (cAMP). Peningkatan cAMP intraseluler oleh adenil siklase $^{(21)}$ mengaktifkan sistem intraseluler. ${ }^{(28,29,30)}$ Tahap berikutnya, molekul cAMP mengaktifkan kinase-A untuk mengaktifkan gen yang resposif.

Penelitian terkini memperlihatkan bahwa SHBG dapat dijadikan marker (petanda) kelainan klinik. ${ }^{(31)}$ Selain itu, hasil penelitian memperlihatkan bahwa pada pria, polimorfisme molekul protein SHBG tidak mempengaruhi kadar SHBG maupun testosteron, ${ }^{(32)}$ tetapi pada wanita post menopause yang diberi suplementasi isoflavone ternyata kadar SHBG serum menurun. (33) Lebih jauh juga telah diperlihatkan hubungan antara indeks masa tubuh (IMT), genotipe SHBG variant, asupan karbohidrat, protein dan lemak dengan status kekurangan energi kronik pada perempuan usia subur. ${ }^{34}$ Penelitian yang lain memperlihatkan bahwa kadar SHBG yang rendah berhubungan dengan resiko sindrom metabolik, antara lain diabetes, obesitas, dan penyakit kardiovaskuler. ${ }^{(35)}$ Lebih khusus diperlihatkan bahwa kadar testosteron total dan testosteron bebas serta SHBG berdampak terhadap penyandang diabetes melitus tipe 2 dan sindrom metabolik. ${ }^{(36)}$ Karena kadar SHBG sangat memengaruhi hasil tes untuk hormon testosteron dan variabilitas yang tinggi antar individu dalam populasi, maka pemeriksaan kadar SHBG harus dipertimbangkan untuk pria yang diduga mengalami defisiensi testosteron. ${ }^{(37)}$

\section{KESIMPULAN}

Berdasar uraian studi literatur di atas dapat disimpulkan bahwa protein SHBG merupakan produk gen SHBG yang terletak pada kromosom $17 \mathrm{p}$ 3.1. Gen SHBG pada hepatosit mengkode protein SHBG, protein tersebut selanjutnya disekresikan ke sistem sirkulasi. Protein SHBG di dalam sistem sirkulasi berfungsi untuk mengikat hormon steroid seks dan memperantarai aksi hormon tersebut ke sel sasaran. Gen SHBG di dalam hepatosit memiliki kesamaan dengan gen androgen binding protein (ABP) di sel Sertoli dalam testis. Proterin ABP berfungsi memperantarai aksi hormon steroid seks di dalam testis. 


\section{KONFLIK KEPENTINGAN}

Penulis menyatakan tidak ada konflik kepentingan.

\section{DAFTAR REFERENSI}

1. Human Genome Project Completion: Frequently Asked Questions. National Human Genome Research Institute (NHGRI). Retrieved 2019-0202. https://www.genome.gov/.../human-genomeproject-completion-frequently-asked-que...

2. Hogeveen KN, Cousin P, Pugeat M, et al. Human sex hormone-binding globulin variants associated with hyperandrogenism and ovarian dysfunction. J Clin Invest, 2002, 109(7):973-81. https://www. ncbi.nlm.nih.gov/pubmed/11927624

3. Nakhla AM, Hryb DJ, Rosner W, et al. Human sex hormone-binding globulin gene expressionmultiple promoters and complex alternative splicing. BMC Mol Biol, 2009, 10:37. https:// www.ncbi.nlm.nih.gov/pubmed/19416531

4. Gershagen S, Lundwall $A$ and Fernlund P. Characterization of the human sex hormone binding globulin (SHBG) gene and demonstration of two transcripts in both liver and testis. Nucl Acid Res, 1998, 17: 9245-9528. https://www.ncbi. nlm.nih.gov/pmc/articles/PMC335128/

5. Hammond GL, Underhill DA, Rykse HM, et al. The human sex hormone-binding globulin gene contains exons for androgen-binding protein and two other testicular messenger RNAs. Mol Endocrinol, 1989, 3:1869-1876. https://www.ncbi. nlm.nih.gov/pubmed/2608061

6. Kahn SM, Hryb DJ, Nakhla AM, et al. Beyond carrier proteins: Sex hormone-binding globulin is synthesized in target cells. J Endocrinol, 2002, 175:113-120. https://joe.bioscientifica.com/ downloadpdf/journals/joe/175/1/113.xml

7. Petra PH, Stanczyk FZ, Namkung PC, et al. Direct effect of steroid-binding protein (SBP) of plasma on the metabolic clearance rate of testosterone in the Rhesus macaque. J Steroid Biochem, 1985, 22:739-746. https://www.sciencedirect.com/ science/article/pii/0022473185902808

8. Joseph DR. (1994) Structure, function and regulation of androgen binding protein/sex hormone binding globulin (SHBG). Vitam Horm, 1994, 49:197-204. https:/www.ncbi.nlm.nih.gov/ pubmed/7810071

9. Turner EE., Ross JBA, Namkung PC et al. Purification and characterization of the sex steroid binding protein from macaque serum. Comparison with the human protein. Biochem, 1984, 23:492 $497 . \quad$ https://pubs.acs.org/doi/abs/10.1021/ bi00298a014

10. Joseph DR, Hall SH and French FS. Rat androgen binding protein. Evidence for identical subunits and amino acid sequence homology with human sex hormone-binding globulin. Proc Natl Acad Sci, 1987, 84:339-343. https://www.ncbi.nlm.nih. gov/pubmed/2432609

11. Sui LM, Lennon J, Ma C, et al. Heterologous expression of wild type and deglycosylated human sex steroid-binding protein (SBP or SHBG) in the yeast, Pichia pastoris. Characterization of the recombinant proteins. J Ster Biochem and Mol Biol, 1999, 68:119-127. https://www.ncbi.nlm. nih.gov/pubmed/10369409

12. Bocchinfuso WP, Ma KL, Lee WM, et al. Selective removal of glycosylation sites from sex hormone- binding globulin by site-directed mutagenesis. Endocrinol, 1992, 1:2331-2336. https://www.ncbi. nlm.nih.gov/pubmed/1425432

13. Cousin P, Dechaud H, Grenot C, et al. Human variant sex hormone-binding globulin (SHBG) with an additional carbohydrate chain has a reduced clearance rate in rabit. $\mathrm{J}$ Clin Endocrinol Metab, 1998, 83:235-240. https://www.ncbi.nlm. nih.gov/pubmed/9435448

14. Power SG, Bocchimfuso WP, Pallesen M, et al. Molecular analysis of human sex hormonbinding globulin variant: evidence for an additional carbohydrate chain. J Clin Endocrinol Metab, 1992, 75:1066-1070. https://www.uniprot.org/ citations/ 1400872

15. Hansson V. Further characterization of the 5a-dihydrotestosterone binding protein in the epididymal cytosol fraction. In vitro studies. Steroids, 1972, 20:575-596. https:// www.sciencedirect.com/science/article/ pii/0039128X72900165

16. Hammond GL, Underhill DA, Smith CL, et al. The cDNA-deduced primary structure of human sex hormone-binding globulin and location of its steroid-binding domain. FEBS Lett. 1987, 215:100-104. https://www.ncbi.nlm.nih.gov/ pubmed $/ 3569533$

17. Petra $\mathrm{PH}$. The plasma sex steroid binding protein (SBP or SHBG). A critical review of recent developments on the structure, molecular biology, and function. J Steroid Biochem Mol Biol, 1991, 40:735-753. $\quad$ https://www.ncbi.nlm.nih.gov/ pubmed/1958572

18. Beck K, Gruber T, Ridgeway CC, et al. Secondary structure and shape of plasma sex steroid-binding protein. Comparison with domain $\mathrm{G}$ of laminin results in structural model of plasma sex steroidbinding protein. Eur J Biochem, 1997, 247:339347 . onlinelibrary.wiley.com/doi/10.1111/j.14321033.1997.00339.x/pdf

19. Hammond GL and Bocchinfuso WP. Sex hormonebinding protein: steroid-binding and dimerization domains. J Steroid Biochem Mol Biol, 1995, 53:543-552. https://www.sciencedirect.com/ science/article/pii/096007609500110L

20. Rosner W, Hryb DJ, Khan MS, et al. Sex hormonebinding globulin mediates steroid hormone signal transduction at the plasma membrane. J Steroid Biochem Mol Biol, 1999, 69:481-485. https:// www.ncbi.nlm.nih.gov/pubmed/10419028

21. Hryb DJ, Nakhla AM, Khan MS, et al. Sex hormone-binding globulin in the human prostate is locally synthesized and may act as an autocrine/ paracrine effector. J. Biol. Chem.2002, 277:2661826622. www.jbc.org/content/277/29/26618.full

22. Dunn JF, Nisula BC and Rodbard D. Transport of steroid hormones: binding of 21 endogenous steroids to both testosterone-binding globulin and corticosteroid-binding globulin in human plasma. J Clin Endocrinol Metab, 1981, 53:58-68. https:// www.ncbi.nlm.nih.gov/pubmed/7195404

23. Parwanto, MLE. The negative correlation between testosterone levels and age in healthy Indonesian men residing in the special capital province of Jakarta, Indonesia. IJRMS, 2017, 5(8):34313437. www.msjonline.org. DOI: http://dx.doi. org/10.18203/2320-6012.ijrms20173535

24. Alberts B, Bray D, Lewis J, et al. Molecular Biology of the cell. Third ed. hal. 1994:729-730. Garland Publishing, Inc. New York \& London. 
https://www.ncbi.nlm.nih.gov/books/NBK21054/

25. Rudolph LM, Cornil CA, Mittelman-Smith MA, et al. Actions of Steroids: NewNeurotransmitters. J Neurosci, 2016, 36(45):11449-11458. www. jneurosci.org/content/jneuro/36/45/11449.full.pdf

26. Hryb DJ, Khan MS, Romas NA et al. The control of the interaction of sex hormone-binding globulin with its receptor by steroid hormones. J Biol Chem, 1990, 265:6048-6054. https://www.ncbi.nlm.nih. gov/pubmed $/ 2156840$

27. Nakhla AM, Leonrad J, Hryb DJ et al. Sex hormone-binding globulin receptor signal transduction proceeds via a $\mathrm{G}$ protein. Steroid, 1999, 4:213-216. https://www.ncbi.nlm.nih.gov/ pubmed/10400382

28. Fortunati N, Fissore F, Fazzari A, et al. The membrane receptor for sex steroid binding protein is not ubiquitous. J Endocrinol Invest, 1992, 15:617-620. https://link.springer.com/ content/pdf/10.1007/BF03344935.pdf

29. Krupenko SA, Krupenko NI and Danzo BJ. Interaction of sex hormone-binding globulin with plasma membranes from the rat epididymis and other tissues. J Steroid Biochem Mol Biol, 1994, 51:115-124. https://www.ncbi.nlm.nih.gov/ pubmed/7947346

30. Porto CS, Lazari MF, Abreu LC, et al. Receptors for androgen-binding proteins: Internalization and intracellular signaling. J Steroid Biochem Mol Biol, 1995, 53:561-565. https://www.ncbi.nlm.nih. gov/pubmed/7626510

31. Goldštajn MŠ, Toljan K, Grgić F, et al. Sex Hormone Binding Globulin (SHBG) as a Marker of Clinical Disorders. Coll Antropol. 2016 40(3):211-218. https://www.ncbi.nlm.nih.gov/ pubmed/29139641

32. Parwanto MLE, Suweino S, Tjahjadi D, et al. The effect of sex hormonebinding globulin (SHBG) protein polymorphism on the levels of SHBG, testosterone, and insulin in healthy Indonesian men. Int J Med Sci Public Health 2016;5:799806. http:/www.ijmsph.com; DOI: 10.5455/ ijmsph.2016.17122015293

33. Parwanto MLE, Indrawati $Y$ and Setiawan $H$. Isoflavone supplementation reduced serum sex hormonebinding globulin concentration in postmenopausal women. Universa Medicina, 2012, 31(1):52-62. https://www.univmed.org/ ejurnal/index.php/medicina/article/view/113

34. Parwanto MLE \& Senjaya H. Dietary intake of mother in childbearing age with BMI $<18.5 \mathrm{~kg} /$ $\mathrm{m} 2$ and has heterozygous variant D327N SHBG genotype (w/v). Int J Community Med Public Health 2017;4:409-417. http://www.ijcmph.com. DOI: $\quad$ http://dx.doi.org/10.18203/2394-6040. ijcmph20170264

35. Yamazaki H, Kushiyama A, Sakoda H, et al. Protective effect of sex hormone-binding globulin against metabolic syndrome: in vitro evidence showing anti-inflammatory and lipolytic effects on adipocytes and macrophages. Hindawi Mediators of Inflammation. 2018, Article ID 3062319, 12 pages. https://doi.org/10.1155/2018/3062319.

36. Mohammed M, AL-Habori M, Abdullateef A, et al. Impact of Metabolic Syndrome Factors on Testosterone and SHBG in Type 2 Diabetes Mellitus and Metabolic Syndrome. Hindawi Journal of Diabetes Research. 2018, Article ID 4926789, 8 pages https://doi.org/10.1155/2018/4926789.

37. Krakowskya Y, Connersa W, Morgentaler A.
Serum Concentrations of Sex Hormone-binding Globulin Vary Widely in Younger and Older Men: Clinical Data from a Men's Health Practice. European Urology Focus, Published online: June 3, 2017 (Article in Press, abstract). DOI: https:// doi.org/10.1016/j.euf.2017.05.00. 